Article

\title{
Environmental Impact Assessment of Remediation Strategy in an Oil Spill in the Ecuadorian Amazon Region
}

\author{
Karina García-Villacís ${ }^{1,2}$, Luis Ramos-Guerrero ${ }^{3, * \mathbb{D}}$, José Luis Canga ${ }^{4}$, Daniel Hidalgo-Lasso ${ }^{1}$ (D) and \\ Paul Vargas-Jentzsch 5 (D)
}

1 Centro de Investigación de Tecnologías Ambientales del Proyecto Amazonía Viva, Empresa Pública Eppetroecuador, $4 \frac{1}{2} \mathrm{~km}$ vía Joya de los Sachas-Coca, Joya de los Sachas 2201010, Ecuador; karina.garcia@eppetroecuador.ec (K.G.-V.); daniel.hidalgo@eppetroecuador.ec (D.H.-L.)

2 Departamento de Ciencias de la Tierra y la Construcción, Universidad de las Fuerzas Armadas-ESPE, Av. General Rumiñahui s/n, Sangolquí 171103, Ecuador

3 Centro de Investigación de Alimentos, CIAL, Universidad UTE, Av. Mariscal Sucre y Mariana de Jesús, Quito 170527, Ecuador

4 Instituto Superior de Medio Ambiente ISM, Av. Padre de Ramón y Cajal 111, 2F, 28043 Madrid, Spain; jlcangacab@gmail.com

5 Departamento de Ciencias Nucleares, Escuela Politécnica Nacional, Ladrón de Guevara E11-253, Quito 170525, Ecuador; paul.vargas@epn.edu.ec

* Correspondence: luis.ramos@ute.edu.ec; Tel.: +593-980548444

check for updates

Citation: García-Villacís, K.; Ramos-Guerrero, L.; Canga, J.L.; Hidalgo-Lasso, D.; Vargas-Jentzsch, P. Environmental Impact Assessment of Remediation Strategy in an Oil Spill in the Ecuadorian Amazon Region. Pollutants 2021, 1, 234-252. https:// doi.org/10.3390/pollutants1040019

Academic Editor:

Malarvannan Govindan

Received: 9 July 2021

Accepted: 25 November 2021

Published: 28 November 2021

Publisher's Note: MDPI stays neutral with regard to jurisdictional claims in published maps and institutional affiliations.

Copyright: (c) 2021 by the authors. Licensee MDPI, Basel, Switzerland. This article is an open access article distributed under the terms and conditions of the Creative Commons Attribution (CC BY) license (https:// creativecommons.org/licenses/by/ $4.0 /)$.
Abstract: Past petroleum-extraction activities in Ecuador have contaminated its Amazon region. To assess the environmental impact attributed to remediation activities regarding the cleanup of these oil spills, two scenarios were studied according to Life Cycle Analysis methodology: (1) No-action, which means to leave the contamination in place without any further action and (2) Environmental remediation, where the environmental-load attributed to the remediation of the representative oil spill was studied. Results indicated that the no-action scenario presented a higher environmental impact for 12 out of the 16 environmental categories evaluated (climate change, ozone depletion, human toxicity non-cancer effects, particulate matter, ionizing radiation human health, ionizing radiation ecosystem, photochemical ozone formation, acidification, terrestrial eutrophication, marine eutrophication, freshwater ecotoxicity, mineral, fossil and renewable resource depletion). Moreover, the no-action scenario presented a global weighted score of contamination of 5.45 points, while the remediation scenario got a score of 3.3 points, which means that the remediation decreased by $39 \%$ of the global environmental impact due to the remediation activity applied, showing the positive influence of environmental remediation to mitigate the effects attributed to the presence of pollution sources associated to the petroleum industry in the Ecuadorian Amazon region.

Keywords: climate change; oil pollution; life cycle assessment LCA

\section{Introduction}

Petroleum is among the main Ecuadorian products of exportations [1], every year representing around $40 \%$ of total exportations and contributing $9 \%$ of the Gross Domestic Product in 2019 [2]. The Ecuadorian petroleum industry started in the 1970s [3], mainly in the Amazon region (east of the country) with 112 oil fields, and also in the coastal region with two oil fields [4]. However, despite the economic importance of the petroleum industry for the country, environmental damages attributable to these activities were left behind. For example, wastes resulting from the oil exploration and production activities (sludge, oil, water and drill cuttings, and others) were disposed of in the vicinity of the extraction facilities without any treatments $[5,6]$. As a consequence, these areas have environmental liabilities that require attention. In general, environmental liability is associated with a source of pollution and tends to increase over time [5]. 
On the other hand, the demographic growth had a strong influence on the appearance of new settlement, some of them in the influence area of (former) petroleum facilities [3]. Moreover, the expansion of agricultural frontiers due to the need of increasing the food production can also result in human health problems that result from the environmental liabilities of the petroleum industry. Rural populations and indigenous communities are clearly the most affected human groups. The affectation of soil, water, flora and fauna, attributable to inappropriate practices of the petroleum industry was largely studied [7-9]. In addition, several reports on the negative effects on human health due to the exposure of humans to compounds associated with petroleum extraction manifesting as skin, digestive, respiratory, pregnancy and reproductive diseases, among others, were widely reported [10-12].

In this regard, the Ecuadorian government has executed several projects for the closure and remediation of the environmental liabilities associated with the petroleum industry in the Ecuadorian Amazon region since 2005. These projects involve a variety of activities including cleaning, remediation, reshaping, and revegetation of areas polluted, mainly, in the provinces of Francisco de Orellana and Sucumbíos [5,6].

Environmental remediation is "the removal of pollutants or contaminants from groundwater, surface water, soil, and sediment" [13]. Indeed, one of the most important goals of environmental remediation is the recovery of polluted areas to improve the living conditions of their inhabitants. However, traditional remediation activities also demand the use of a considerable number of natural resources, fossil fuels, energy and human labor. Therefore, they also generate hazardous and non-hazardous wastes, as well as gaseous emissions. Consequently, a negative environmental impact can be also attributed to remediation activities $[14,15]$ and must be taken into consideration. Therefore, a cost-benefit analysis of these activities is necessary. A quantification of the negative impacts is also required to propose improvement strategies to lower the global impact.

In this sense, life cycle assessment (LCA) is an option to evaluate the environmental behavior of products or process. In fact, LCA was previously used for the evaluation of remediation technologies in various scenarios, such as soil pollution by heavy metals, polychlorinated biphenyls and volatile organic compounds (VOC) [14,16-21]. During LCA evaluation, the identification of primary and secondary impacts in remediation technologies is important; primary impacts are those related to residual contamination left in the subsurface during and after remediation, while secondary impacts refer to the consumption of resources and generation of emissions in other stages of the remediation life cycle of the project [14].

This study assesses the environmental impact of the remediation activities of an environmental liability attributed to the petroleum industry, which contemplate clearing and solid waste collection, construction of facilities, soil washing, reshaping and revegetation. Two scenarios were compared: (1) the environmental remediation of a representative oil spill (i.e., the release of a liquid petroleum hydrocarbon into the environment) that occurred in the 90s decade, and (2) a no-action scenario, that means no execution of any action of remediation, leaving the environmental liability in its place with no anthropogenic influence in the slow degradation of pollutants. This led us to consider how to improve the current strategies of environmental remediation applied in the Amazon Region of Ecuador.

\section{Materials and Methods}

\subsection{Study Site}

Environmental remediation activities for an oil spill from the Sacha 124 well that occurred more than a decade ago were evaluated. The environmental liability was codified as SA_124_02D (total remediated area of $2701.84 \mathrm{~m}^{2}$ ) by the government institution. It is located at Canton Joya de los Sachas (Francisco de Orellana province) in the Ecuadorian Amazon region (Coordinates: 9,957,666.78 N, 289,612.60 E). The site is at 275 masl. It has an average annual temperature of 23 to $25^{\circ} \mathrm{C}$, relative humidity of $90 \%$ and an annual precipitation of $4500 \mathrm{~mm}$. The soil in the area is shallow and has rocky outcrops with 
limitations for agricultural, livestock and forestry activities [22]. This environmental liability was chosen as a case of study due to the availability of data and for representing a common scenario in the activities of remediation carried out in this region.

\subsection{Environmental Remediation Activities}

The remediation strategy involves the following steps (a) clearing of solid waste, (b) construction of facilities, (c) washing of soil contaminated with crude oil, (d) reshaping of the affected area and (e) revegetation. These activities require the use of heavy machinery (excavators, dump trucks), pumps and vehicles for the mobilization of people as well as for the transport of tools and equipment. Furthermore, workers wear uniforms and specific personal protective equipment (PPE) such as gloves, helmets, masks, protective suits against chemical agents and raincoats. Taking into account that these materials are considered to be hazardous waste and are incinerated at the end of their lifetime, their volume was quantified through detailed records in the waste delivery manifests.

Additionally, there are other activities included, such as the measurement of affected area with basic topographic techniques [23]; the monitoring of the concentration of Total Petroleum Hidrocarbons (TPH) in the soil before, during and after remediation [24] until the concentration of TPH is under the limits that are established in environmental regulations [25]; and the socialization of the remediation activities to owners of the affected area to obtain their authorization. However, these activities are not considered in the study because they do not demand a considerable consumption of resources. The remediation activities evaluated in this study encompass the following phases that are developed in a continuous and parallel way.

\subsubsection{Clearing of Solid Waste}

This consists of removing the vegetation and collecting other wastes. It involves the use of excavators and dump trucks to remove the entire surface layer from the area to be intervened. Contaminated vegetation is taken to treatment centers for composting and uncontaminated vegetation is reincorporated into the site when intervention activities are completed.

\subsubsection{Construction of Facilities}

Pedestrian and vehicular accesses, places where workers can take a break, waste collection sites, and other facilities are needed. They must be built, and heavy machinery is needed.

\subsubsection{Soil Washing}

In oil spills such as the case of the study, the predominant contaminant is crude oil, and the main affected matrix is soil. According to the experience of the government institution in charge of remediation activities, in similar scenarios, the best technique to recover the soil is in situ soil washing with water and biodegradable surfactants (e.g., limonene-based) to facilitate the removal of hydrocarbons (hydrophobic contaminants). Water is taken from nearby water bodies. The use of pressure pumps allows for the generation of turbulent conditions for the cleanup of the soil (contaminants are released from the soil). The activity is carried out until the presence of contamination is not visually distinguishable. In this stage, the crude oil is recollected and transported to a recuperation plant for its final reincorporation into national production. After soil washing, physical-chemical analyses of the used water are carried out and, if values of relevant parameters comply with the limits established in Environmental Regulations [26], it can be discharged into the environment; otherwise, the water must be treated before its discharge, for example by coagulation and flocculation [27]. 


\subsubsection{Reshaping and Revegetation}

The remediation of soil is completed when the concentrations of pollutants comply with permissible limits established in Environmental Regulations [25]. After, the facilities are dismantled and the intervened area is reshaped, taking into account the original topography, and revegetated with native species.

\subsection{Life Cycle Assessment ( $L C A)$}

LCA was carried out according to the procedure of the Standards ISO 14040 (2006) and ISO $14044(2006)[28,29]$. The aspects and/or components needed to perform the LCA are briefly described in the following.

\subsubsection{Scope}

Environmental remediation activities carried out in the oil spill SA_124_02D were analyzed and compared with the no-action scenario. The study is descriptive, and the limits of the system are visualized in Figure 1, which represents all activities from the environmental remediation process.

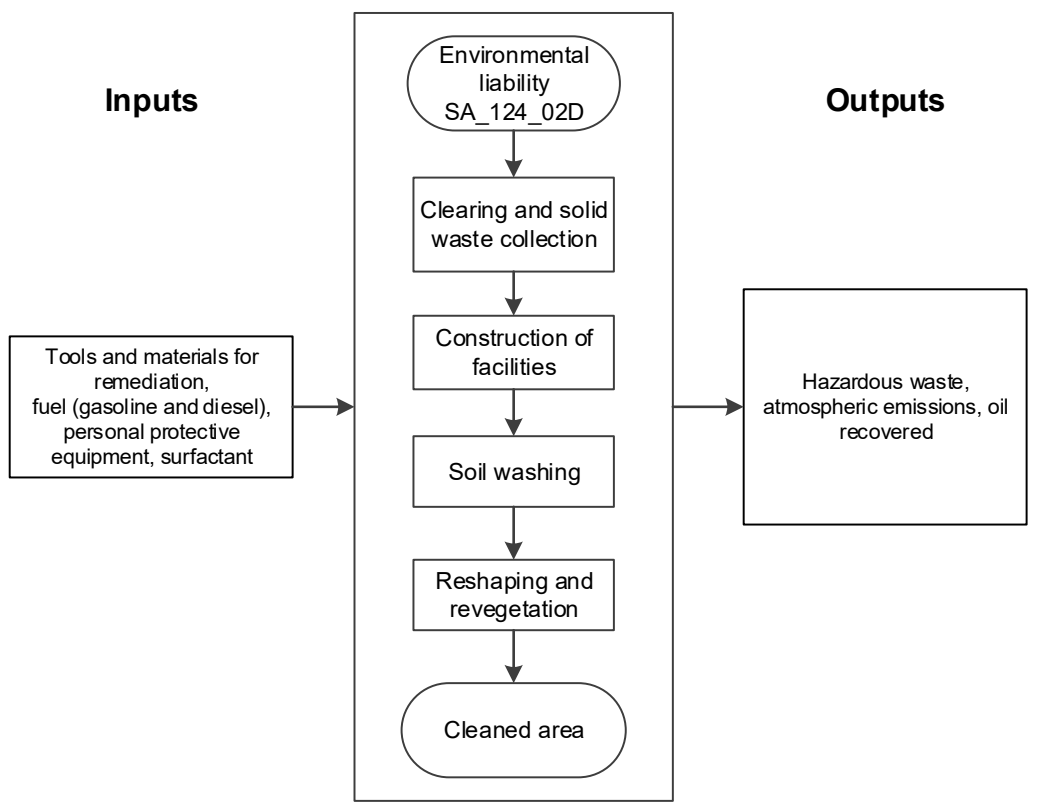

Figure 1. System boundary of remediation activities scenario.

\subsubsection{Life Cycle Inventory}

To quantify the inputs and outputs of the system, data were collected throughout the described remediation process. The main collected and/or calculated data were:

- Fuel consumption (diesel and gasoline) for the operation of vehicles and mobile equipment, the total mileage for the vans and the $\mathrm{km} / \mathrm{t}$ for the trucks.

- The volume of the biodegradable limonene-based surfactant. The composition of this product was obtained from the technical sheets available from the distributor.

- The volume of crude oil recovered from the cleaned oil spill, which was incorporated into national production.

- Use and consumption of tools and materials for remediation and PPE were considered. Subsequently, the predominant component of each item was determined by reviewing the manufacturer's technical data sheets, as shown in Table 1. 
Table 1. Main components of tools, supplies and personal protective equipment in the environmental remediation process.

\begin{tabular}{|c|c|c|c|}
\hline $\begin{array}{l}\text { Personal Protection } \\
\text { Equipment }\end{array}$ & Weight (g) & Principal Component & Weight (g) \\
\hline Sitex bib overall & 800 & PVC plastic & 800 \\
\hline \multirow{3}{*}{ Gloves_PVC dotted (pair) } & \multirow{3}{*}{4} & Natural cotton fibers $45 \%$ & 1.8 \\
\hline & & Polyamide $45 \%$ & 1.8 \\
\hline & & PVC $10 \%$ & 0.4 \\
\hline Long nitrile gloves (pair) & 150 & Nitrile & 150 \\
\hline Short nitrile gloves (pair) & 175 & Nitrile & 175 \\
\hline $\begin{array}{c}\text { Protective suit against } \\
\text { chemical agents }\end{array}$ & 42.5 & High-density polyethylene & 83 \\
\hline \multirow{2}{*}{ Clear glasses } & \multirow{2}{*}{25} & Polycarbonate $(66 \%)$ & 16.5 \\
\hline & & PVC plastic (34\%) & 8.5 \\
\hline Waterproof jacket & 200 & Polyamide with polyurethane coating & 108 \\
\hline Disposable hearing aids & 3 & Hypoallergenic foam & 3 \\
\hline \multirow{2}{*}{ Dark glasses } & \multirow{2}{*}{25} & Polycarbonate $(66 \%)$ & 16.5 \\
\hline & & PVC (Polyvinyl chloride) plastic (34\%) & 8.5 \\
\hline \multirow{5}{*}{$\begin{array}{l}\text { Rubber boots with steel tip } \\
\text { (pair) }\end{array}$} & \multirow{5}{*}{1500} & Reinforcement on the toe: modified PVC: $50 \%$ & 750 \\
\hline & & Lining: polyester $5 \%$ & 75 \\
\hline & & Tip: $1.5 \mathrm{~mm}$ thick antistatic steel; $25 \%$ & 375 \\
\hline & & Shoe sole: nitrile $10 \%$ & 150 \\
\hline & & Shoe insole: cotton and foam rubber $10 \%$ & 150 \\
\hline \multirow{5}{*}{ Leather boots (pair) } & \multirow{5}{*}{1260} & Reinforcement on the toe: 22-gauge waterproof leather: $50 \%$ & 630 \\
\hline & & $\begin{array}{l}\text { Shoe sole: polyurethane with thermoplastic polyurethane: } \\
\qquad 10 \%\end{array}$ & 126 \\
\hline & & Tip1.5 mm thick antistatic steel; 25\% & 315 \\
\hline & & Shoe insole: cotton and foam rubber $10 \%$ & 126 \\
\hline & & Lining: polyester $5 \%$ & 63 \\
\hline \multirow{6}{*}{$\begin{array}{l}\text { Aerosol and particulate } \\
\text { respirator }\end{array}$} & \multirow{6}{*}{15} & Outer layer: polyester $40 \%$ & 6 \\
\hline & & $\begin{array}{l}\text { Electrostatic filter: polypropylene microfibers with ACMB } \\
\text { (Activate Carbon Melting Blowering) technology } 15 \%\end{array}$ & 2.25 \\
\hline & & Inner layer: polypropylene $30 \%$ & 4.5 \\
\hline & & Nasal pad: high-density foam, $5 \%$ & 0.75 \\
\hline & & $\begin{array}{l}\text { Elastic band: synthetic rubber braided with latex-free } \\
\text { polyester, } 5 \%\end{array}$ & 0.75 \\
\hline & & Adjustment clip: polypropylene 5\% & 0.75 \\
\hline \multirow{2}{*}{ Nappa gloves (pair) } & \multirow{2}{*}{8} & Cowhide leather (nappa) (80\%) & 6.4 \\
\hline & & Natural cotton $(20 \%)$ & 1.6 \\
\hline \multirow{2}{*}{$\begin{array}{c}\text { Gas and vapor mask } \\
\text { (half face) }\end{array}$} & \multirow{2}{*}{168} & Silicone $(60 \%)$ & 100.8 \\
\hline & & Nylon $(40 \%)$ & 67.2 \\
\hline \multirow{4}{*}{ Vapor filter } & \multirow{4}{*}{8.63} & Activated carbon: $70 \%$ & 6.041 \\
\hline & & Polyestyrene: 22\% & 1.8986 \\
\hline & & Carbon treatment: $4 \%$ & 0.3452 \\
\hline & & Polyester: $4 \%$ & 0.3452 \\
\hline Helmets & 360 & Polyestyrene & 360 \\
\hline
\end{tabular}

The same area of $2701.84 \mathrm{~m}^{2}$ was considered for the no-action scenario. In fact, the weight of hydrocarbons contained in this amount of soil was determined as $80,136 \mathrm{~kg}$ of TPH.

Specific data for the reshaping and revegetation stage was not available. Therefore, required resources for this stage were estimated. Similar requirements for the phase of access routes and facility construction were assumed. Long-lasting materials such as tools and equipment for laboratory analysis were not considered. The specific assumptions and 
limitations of this study are summarized in Table S1. The complementary information needed for the usual process was taken from Ecoinvent LCI Database [30].

\subsubsection{LCA Evaluation}

The modeling of the flow of materials and the calculations of associated environmental impacts were carried out using SimaPro software (PRé Sustainability B.V., Amersfoort, The Netherlands) [31], together with ILCD (International Reference Life Cycle Data System) 2011 Midpoint + V1.10/EC-JRC Global methodology [32] and Ecoinvent Databases [30]. The unknown data of the process is complemented by the information of the Ecoinvent Database.

The environmental categories analyzed in this work were climate change, particulate matter, ozone layer depletion, eutrophication (terrestrial, freshwater and marine), human toxicity (carcinogenic and non-carcinogenic effects), ionizing radiation for human health, ionizing radiation for ecosystems, acidification, freshwater ecotoxicity, photochemical ozone formation, mineral, fossil and renewable resource depletion, land use and water resource depletion.

Environmental impact from the characterization stage were calculated. A weighting methodology proposed in an earlier report [33] was also applied in this work. In this regard, extractions and emissions measured worldwide were taken as reference factors for each of the values of the environmental categories evaluated, and then transformed to dimensionless values (points) [33]. In this way, the comparison of the categories affected by specific characteristics of the scenarios was possible. Furthermore, the results of some categories were grouped to show the end-point environmental effects. In this regard, the "resource depletion effect" is represented by the climate change, ozone depletion, photochemical ozone formation, land use, water resource depletion, mineral-fossil and renewable resource depletion categories. The "human health impacts" contemplate human toxicity-non cancer effects, human toxicity-cancer effects, particulate matter and ionizing radiation human health categories, while "ecosystem impacts" are formed by acidification, terrestrial-, freshwater- and marine-eutrophication and freshwater ecotoxicity.

\section{Results}

\subsection{Life Cycle Inventory}

The life cycle inventory was generated for both scenarios. The results are summarized in Table 2.

\subsection{Environmental Impact in Each Environmental Category of LCA}

Table 3 shows the results of the environmental impact assessment obtained by LCA in the characterization stage with the corresponding percentages for each category, thus providing a trend of the behavior of each indicator for each scenario. Also, weighted midpoint results for each category in both scenarios are included in Table 3. 
Table 2. Life cycle inventory for the environmental remediation and non-action scenarios.

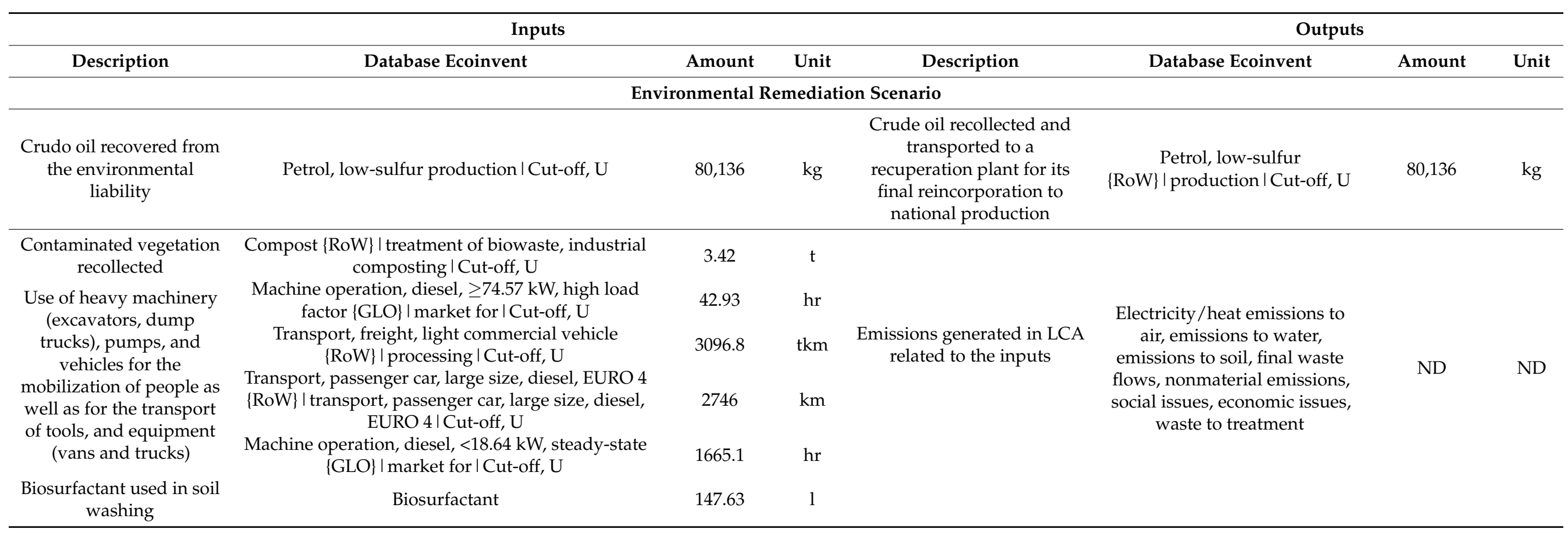


Table 2. Cont.

\begin{tabular}{|c|c|c|c|c|c|c|c|}
\hline \multicolumn{5}{|c|}{ Inputs } & \multicolumn{3}{|c|}{ Outputs } \\
\hline Description & Database Ecoinvent & Amount & Unit & Description & Database Ecoinvent & Amount & Unit \\
\hline \multirow{12}{*}{$\begin{array}{l}\text { Principal componentes } \\
\text { in PEE, tools and } \\
\text { materials used in } \\
\text { remediation activities }\end{array}$} & $\begin{array}{l}\text { Polyvinylidenchloride, granulate } \\
\{\text { RoW }\} \text { | production I Cut-off, } U\end{array}$ & $22,135.1$ & $\mathrm{~g}$ & \multirow{12}{*}{$\begin{array}{l}\text { Hazardous waste sent to } \\
\text { incineration }\end{array}$} & \multirow{12}{*}{$\begin{array}{l}\text { Hazardous waste, for } \\
\text { incineration }\{\text { RoW } \mid \text { I treatment } \\
\text { of hazardous waste, hazardous } \\
\text { waste incineration I Cut-off, } U\end{array}$} & \multirow{12}{*}{$278,772.05$} & \multirow{12}{*}{$\mathrm{g}$} \\
\hline & $\begin{array}{l}\text { Seal, natural rubber based } \\
\{\text { RoW } \mid \text { production } \mid \text { Cut-off, } U\end{array}$ & 7629.66 & $\mathrm{~g}$ & & & & \\
\hline & Nylon $6\{$ RoW $\}$ I production I Cut-off, U & 9358.33 & $\mathrm{~g}$ & & & & \\
\hline & Synthetic rubber $\{$ RoW $\}$ I production I Cut-off, $U$ & $10,108.33$ & $\mathrm{~g}$ & & & & \\
\hline & Polycarbonate $\{$ RoW $\}$ I production I Cut-off, $U$ & 13,141 & $\mathrm{~g}$ & & & & \\
\hline & $\begin{array}{l}\text { Polyurethane, flexible foam } \\
\{\text { RoW } \mid \text { | production I Cut-off, } U\end{array}$ & $153,066.7$ & $\mathrm{~g}$ & & & & \\
\hline & $\begin{array}{l}\text { Polyester-complexed starch biopolymer } \\
\quad\{\text { RoW }\} \text { I production I Cut-off, U }\end{array}$ & 2564.66 & $\mathrm{~g}$ & & & & \\
\hline & $\begin{array}{c}\text { Steel, low-alloyed }\{\text { RoW }\} \text { I steel production, electric, } \\
\text { low-alloyed I Cut-off, U }\end{array}$ & 9789.69 & $\mathrm{~g}$ & & & & \\
\hline & Cotton fibre $\{$ RoW $\}$ I cotton production I Cut-off, U & $31,213.66$ & $\mathrm{~g}$ & & & & \\
\hline & $\begin{array}{l}\text { Polyethylene, high density, granulate } \\
\{\text { RoW }\} \text { I production I Cut-off, U }\end{array}$ & 179.92 & $\mathrm{~kg}$ & & & & \\
\hline & $\begin{array}{l}\text { Polypropylene, granulate } \\
\{\text { RoW } \mid \text { | production I Cut-off, } U\end{array}$ & $22,025.76$ & $\mathrm{~kg}$ & & & & \\
\hline & Textile, jute $\{$ RoW $\}$ I production I Cut-off, $U$ & 2.37 & $\mathrm{~kg}$ & & & & \\
\hline \multicolumn{8}{|c|}{ Non-action Scenario } \\
\hline $\begin{array}{l}\text { Hydrocarbons spilled to } \\
\text { the ground }\end{array}$ & Petrol, low-sulfur $\{$ RoW $\}$ I production I Cut-off, U & 80,136 & $\mathrm{~kg}$ & $\begin{array}{l}\text { Hydrocarbons recovered } \\
\text { from the soil }\end{array}$ & Petroleum oil & 80,136 & $\mathrm{~kg}$ \\
\hline
\end{tabular}

RoW: Global process excluding the European Union. GLO: Global process. LCA: Life Cycle Analysis. EURO: UE vehicle clasification. ND: No experimental data. 
Table 3. Results of LCA for the no-action and remediation scenarios in the characterization stage.

\begin{tabular}{|c|c|c|c|c|c|c|c|}
\hline \multirow{2}{*}{ Environmental Category } & \multicolumn{3}{|c|}{ Caracterization } & \multicolumn{2}{|c|}{ Percentage $(\%)$} & \multicolumn{2}{|r|}{ Points } \\
\hline & Units & $\begin{array}{l}\text { No-Action } \\
\text { Scenario }\end{array}$ & $\begin{array}{c}\text { Environmental } \\
\text { Remediation Activities }\end{array}$ & $\begin{array}{l}\text { No-Action } \\
\text { Scenario }\end{array}$ & $\begin{array}{c}\text { Environmental } \\
\text { Remediation Activities }\end{array}$ & $\begin{array}{l}\text { No-Action } \\
\text { Scenario }\end{array}$ & $\begin{array}{c}\text { Environmental } \\
\text { Remediation Activities }\end{array}$ \\
\hline Climate change & $\mathrm{kg} \mathrm{CO}_{2}$ eq. & $55,477.99$ & $42,010.33$ & 100 & 75.72 & 0.401 & 0.304 \\
\hline Ozone depletion & $\mathrm{kg} \mathrm{CFC}^{-11}$ eq. & $5.56 \times 10^{-2}$ & $4.35 \times 10^{-3}$ & 100 & 7.83 & 0.172 & 0.013 \\
\hline $\begin{array}{c}\text { Human toxicity, non-cancer } \\
\text { effects }\end{array}$ & CTUh & $3.04 \times 10^{-3}$ & $1.40 \times 10^{-3}$ & 100 & 46.02 & 0.380 & 0.175 \\
\hline Human toxicity, cancer effects & CTUh & $9.97 \times 10^{-5}$ & $5.79 \times 10^{-4}$ & 17.22 & 100 & 0.180 & 1.046 \\
\hline Particulate matter & $\mathrm{kg} \mathrm{PM}_{2.5}$ eq. & 57.45 & 19.75 & 100 & 34.37 & 1.008 & 0.346 \\
\hline $\begin{array}{l}\text { Ionizing radiation human } \\
\text { health }\end{array}$ & $\mathrm{Bq} \mathrm{U}_{235}$ eq. & $18,951.12$ & 1282.53 & 100 & 6.77 & 1.118 & 0.076 \\
\hline $\begin{array}{l}\text { Ionizing radiation ecosystem } \\
\text { (interim) }\end{array}$ & CTUe & $1.34 \times 10^{-1}$ & $9.20 \times 10^{-3}$ & 100 & 6.84 & 0.000 & 0.000 \\
\hline $\begin{array}{l}\text { Photochemical ozone } \\
\text { formation }\end{array}$ & kg NMVOC eq. & 255.40 & 169.50 & 100 & 66.37 & 0.537 & 0.356 \\
\hline Terrestrial eutrophication & molc $\mathrm{N}$ eq. & 583.93 & 540.53 & 100 & 92.57 & 0.221 & 0.205 \\
\hline Freshwater eutrophication & kg P eq. & $5.23 \times 10^{-1}$ & $7.12 \times 10^{-1}$ & 73.51 & 100 & 0.024 & 0.032 \\
\hline Marine eutrophication & $\mathrm{kg} \mathrm{N} \mathrm{eq.}$ & 52.99 & 49.41 & 100 & 93.25 & 0.209 & 0.195 \\
\hline Freshwater ecotoxicity & CTUe & $30,066.81$ & $27,747.30$ & 100 & 92.29 & 0.229 & 0.212 \\
\hline Land use & kg déficit de C & 2544.05 & 4291.63 & 59.28 & 100 & 0.002 & 0.004 \\
\hline Water resource depletion & $\mathrm{m}^{3}$ eq. water & 52.29 & 65.39 & 79.97 & 100 & 0.043 & 0.054 \\
\hline $\begin{array}{l}\text { Mineral, fossil \& renewable } \\
\text { resource depletion }\end{array}$ & $\mathrm{kg}$ Sb eq. & 0.10 & 0.07 & 100 & 73.29 & 0.064 & 0.047 \\
\hline Total & & & & & & 5.448 & 3.305 \\
\hline
\end{tabular}


From the 16 environmental categories subject to evaluation, 12 of the categories showed higher impact values in the no-action scenario than in the environmental remediation scenario. These categories are climate change, ozone depletion, human toxicity with non-carcinogenic effects, particulate matter, ionizing radiation for human health, ionizing radiation for ecosystems, photochemical ozone formation, acidification, terrestrial eutrophication, marine eutrophication, freshwater ecotoxicity and depletion of mineral, fossil and renewable resources. In contrast, the remaining four categories (human toxicity with carcinogenic effects, eutrophication of freshwater, land use and depletion of water resources) showed higher impact values in the environmental remediation scenario. In general, there is a greater environmental impact in the no-action scenario with 5.45 points. Furthermore, between the two scenarios there is a difference of 2.14 points. Therefore, the environmental load for the remediation scenario is lower by $39.4 \%$.

\subsection{End-Point Results of LCA Categorized by Type of Final Affectation}

Figure 2 shows the impacts for the final affected groups. In all the groups, a lower environmental impact is observed for the remediation scenario. Impacts on ecosystems decreased by $43 \%$ and impacts on human health decreased by $39 \%$. Also, it is important to highlight that impacts on the availability of resources decreased by $36 \%$.

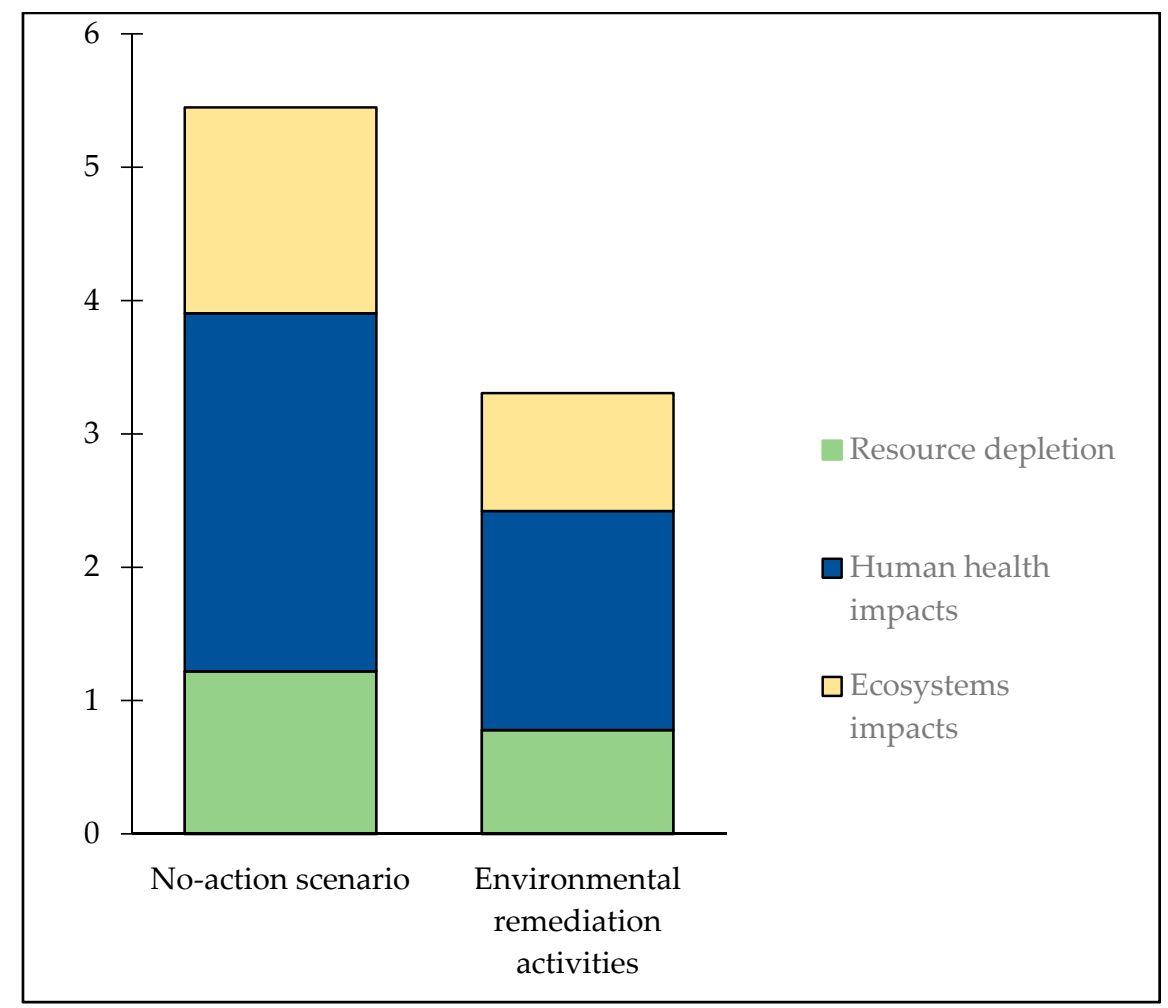

Figure 2. End-point results of LCA (Life Cycle Analysis) categorized by type of final affectation.

\section{Discussion}

The interpretation of the results requires an evaluation in terms of activities included in each scenario that can produce a potential environmental impact. These activities were identified and related to the environmental categories considered for the LCA.

\subsection{Environmental Remediation Scenario}

\subsubsection{Consumption of Fossil Fuels by Heavy Machinery, Vehicles, and Pressure Pumps}

The use of vehicles, heavy machinery and mobile equipment is crucial in all stages of the environmental remediation under consideration. The mobilization of people, the transport of tools and equipment, as well as the removal (and transport) of soil for ex situ 
treatments and the movement of recovered crude oil, require the consumption of fossil fuels. Gasoline and diesel, which have a fossil origin, generate gaseous emissions that are released into the atmosphere. The resulting environmental impacts are related to the following environmental categories:

- Climate change, since the emissions include carbon dioxide $\left(\mathrm{CO}_{2}\right)$, the most known greenhouse gas. However, $\mathrm{CO}_{2}$ is not the only greenhouse gas and other gases such as methane $\left(\mathrm{CH}_{4}\right)$, nitrous oxide $\left(\mathrm{N}_{2} \mathrm{O}\right)$ and ozone-depleting substances (ODS) also contribute to global warming [34]. Combustion processes can produce nitrogen oxides $\left(\mathrm{NO}_{\mathrm{x}}\right)$ [35] and $\mathrm{N}_{2} \mathrm{O}$ [36]. Despite the natural bacterial breakdown of nitrogen in soils and in the oceans is considered to be the main source of $\mathrm{N}_{2} \mathrm{O}$ in the atmosphere, it is recognized that the combustion of fossil fuels and biomass are also contributors that cannot be underestimated [37]. The transport of contaminated soil is responsible for the environmental impacts related to the category of climate change; some authors found that, for distances larger than $200 \mathrm{~km}$ between the remediation site and the soil treatment site, the impact associated with gaseous emissions was significant [38]. Other studies have also reported a significant contribution to the impact in this category due to the use of fossil fuels $[17,39,40]$. In this study the environmental remediation implied a total path traveled by a truck of $6194 \mathrm{~km}$, while the van traveled $2744 \mathrm{~km}$. It is undeniable that impacts associated to the vehicles are considerable and alternatives with less mobilization should be explored.

- Stratospheric ozone depletion, since, as explained before, $\mathrm{N}_{2} \mathrm{O}$ is produced by the combustion of fossil fuels.

- $\quad$ Particulate matter, since it is produced by the incomplete combustion of fossil fuels. The main component of particulate matter that results from the combustion of fossil fuels is black carbon, which absorbs solar radiation and therefore is an important source of global warming [39], together with the health effects mainly impacting the respiratory system. In fact, some authors suggested that black carbon could be the second strongest contributor to global warming after $\mathrm{CO}_{2}[40,41]$.

- Formation of photochemical ozone, since $\mathrm{NO}_{\mathrm{x}}$ and $\mathrm{VOC}$ resulting from vaporization of fuels are precursors of tropospheric $\mathrm{O}_{3}$ and pernitrate species (the most abundant is Peroxyacetyl nitrate, PAN) [35]. Additionally, tropospheric ozone $\left(\mathrm{O}_{3}\right)$ is another gas that contributes to global warming; however, $\mathrm{O}_{3}$ is not regulated by the Kyoto and Paris Protocols likely because it is a secondary pollutant [42].

- Acidification and terrestrial eutrophication, since $\mathrm{NO}_{\mathrm{x}}$ and sulfur dioxide $\left(\mathrm{SO}_{2}\right)$ are emitted due to the combustion of fossil fuels. The emission of $\mathrm{NO}_{\mathrm{x}}$ and $\mathrm{SO}_{2}$ can be explained by taking into account that fossil fuels contain variable amounts of sulfur and nitrogen compounds $[43,44]$. In addition, a high temperature combustion of a fuel in contact with atmospheric nitrogen $\left(\mathrm{N}_{2}\right)$ results also in the formation of $\mathrm{NO}_{\mathrm{x}}$ [45].

- Human toxicity with non-carcinogenic effects, since populations can be exposed to primary and secondary pollutants resulting from the combustion of fuels. Primary pollutants include $\mathrm{CO}_{2}, \mathrm{CO}$, particulate matter, $\mathrm{NO}_{x}$ (fundamentally $\mathrm{NO}$ and $\mathrm{NO}_{2}$ ) and $\mathrm{SO}_{2}$. Secondary pollutants are a variety of photochemically produced gases such as tropospheric $\mathrm{O}_{3}$, particulate matter derived from atmospheric chemical reactions, PAN and other organic compounds occurring in the photochemical smog. Shortterm effects of the exposition to these air pollutants can range from slight temporal discomfort, irritation of the eyes, nose, skin and the respiratory tract, coughing, chest tightness, breathing difficulties, headaches, nausea and dizziness, to more serious conditions such as asthma, pneumonia, bronchitis, and lung and heart problems [46].

4.1.2. Gaseous Emissions and Discharges Generated by the Incineration of Hazardous Waste

PPE and other tools that reached to the end of their lifetime are incinerated to ensure a proper elimination of these wastes. According to some authors [47,48], the incineration of hazardous waste contributes to the following categories: climate change, human toxicity 
with non-carcinogenic and carcinogenic effects, particulate matter, photochemical ozone formation, marine and soil eutrophication, and depletion of mineral, fossil and renewable resources.

Special importance is given to the category of human toxicity with non-carcinogenic and carcinogenic effects due to implications to human health. There are many chemical species that can be produced, and therefore released due to incineration; the most problematic are polycyclic aromatic hydrocarbon (PAH), polychlorinated biphenyls (PCBs), dioxins and furans. Also, flue gas can contain variable concentrations of (heavy) metals, which is usually associated to particulate matter [49]. The generation of carbon monoxide is an inevitable consequence of incomplete combustion and, together with acid gases (e.g., $\mathrm{HCl}, \mathrm{SO}_{2}$ ), is a notable contributor to the hazardous nature of gaseous emissions from incinerators.

4.1.3. Gaseous Emissions and Discharges Related to the Manufacture of Tools and Materials for Remediation Activities and PPE

PPE and tools are used in the remediation process and, at the end of their lifetime, are wastes. In all stages, the processes involved in the environmental remediation requires the use of PPE for the protection of workers since they are in contact with hazardous chemical compounds. The life cycle assessment of the predominant components of PPE is showed in Table S2 (Supplementary Material). The manufacture and use of PPE impacts the environment in all evaluated categories, and, to a lesser extent, leads to ionizing radiation in ecosystems and land use.

4.1.4. Transfer of Crude Oil and Other Chemical Compounds Present in Contaminated Soil and Sediment

In the soil washing phase, turbulent conditions are created to separate crude oil from the soil. This increases the contact of contaminants with the aqueous washing solution, and thus increases the availability of contaminants [50]. Contaminants are transferred to water and a remainder of those substances will be present even in the treated water; therefore, there is an affectation in the category of freshwater toxicity and depletion of water resources. Surfactants are used in soil washing procedures and these substances affect the content of oxygen in the water. The biodegradation of chemical compounds in water requires oxygen and this oxygen is obtained from the dissolved oxygen. Moreover, common surfactants used for remediation purposes [51] contain nitrogen in their structure (e.g., cetrimonium bromide, CTAB and cocamidopropyl betaine, CAPB) and could promote eutrophication.

\subsubsection{Remediation Activities}

Since remediation activities are carried out in many cases manually, mainly in the clearing phase, workers have direct exposure to contaminants. Despite the rigorous use of PPE, the exposure to carcinogenic and non-carcinogenic substances cannot be ruled out. The contribution of the remediation scenario to the categories of ionizing radiation for ecosystems and human health is of particular importance. Crude oil, production sludge, formation waters and gas, among others, are a considerable source of Technologically Natural Radioactive Materials (TENORM). TENORM are accumulated by the high content of radionuclides in rocks (for example: Uranium, Thorium and Radium and their decay products, and Potassium-40) that have existed since the formation of the earth, which are also characterized by the accumulation over time, so they can put human health at risk and damage the environment. Despite being significantly lower compared to no-action, the consequences to human health are a concern for its exposure to radioactive material hydrocarbon compounds [52]. The presence of TENORM in Ecuador has been previously reported, especially in the production of crude oil [53]. 
4.1.6. Emissions and Discharges Resulting from the Reincorporation of Crude Oil Recovered from Environmental Liabilities to National Production

Crude oil recovered from the environmental liability is reincorporated into national production. Its generation of gaseous emissions and discharges when it is finally used would contribute to the category of freshwater ecotoxicity and human toxicity with carcinogenic and non-carcinogenic effects, as verified in previous studies of the life cycle study of crude oil production [54].

\subsubsection{Impact on the Landscape and Soil by the Environmental Remediation Activities}

According to the Simapro software, there are three causes that affect the landscape and land use [55]. This software analyzes the impact on land use based on the Organic Matter Deficit in the soil, which has direct impacts on the fertility and physical-chemical conditions of the soil (infiltration, stability, habitats, and morphology of the site), generating midpoint impacts related to the impact on the production of biotics and biomass, and as a final impact the potential damage to ecosystem services [56]:

- Drainage/irrigation: when the activities of clearing, construction of accesses and surface reshaping are carried out, the natural drainage courses of the bodies of water are modified for the construction of dams to control the effluents during soil washing. Although surface reshaping is carried out based on the initial topography of the site, at the end of the operations, the area of the remediated environmental liability is not exactly equal to the initial area and natural restoration will take a significant amount of time.

- Compaction: surface reshaping affects soil compaction.

- Modification of the vegetation layer: when the revegetation activities of the remediated area are carried out, pioneer plant species are used in the first instance and, since the environmental liabilities are generally located in private properties, plant species of interest of the owner are also planted, changing the species found before the remediation activities and therefore the ecosystem is modified.

\subsection{No-Action Scenario}

By analyzing the no-action scenario, it was determined that environmental impacts may be related to the contamination of natural resources. The study area where remediation activities were carried out has an average annual rainfall greater than $3000 \mathrm{~mm}$ reaching $6000 \mathrm{~mm}$, a relative humidity of $90 \%$, and an average temperature of 23 to $25^{\circ} \mathrm{C}$ [57]. Based on the mentioned climatic conditions, it is highly probable that the pollutants have migrated, following the natural course of the nearby bodies of water. Furthermore, the greater contact of the pollutants with air favors the evaporation of volatile fractions and gaseous emissions.

According to the final disposal routes for hydrocarbons from oil spills [58], the following environmental impacts are identified.

\subsubsection{Water Contamination}

The composition of hydrocarbons in crude oil is diverse, with densities between $0.85-1.04 \mathrm{~g} / \mathrm{cm}^{3}$. In freshwater bodies, the dispersion of pollutants will depend on various factors, such as their density ( $<1$ float; $>1$ sink), the ability to interact with sediments and the intensity of water flows. The contamination of bodies of water by hydrocarbons represents an impact on aquatic life, causing toxic effects at all levels of the trophic chain, affecting phytoplankton, zooplankton, fishes, aquatic birds, mammals and benthic organisms [59]. Water contamination in this scenario would be related to the following environmental categories:

- Human toxicity with carcinogenic and non-carcinogenic effects: compounds classified as carcinogenic by the Agency for Toxic Substances and Disease Registry (ATSDR) that are present in crude oil could include benzene, benzopyrene, benzoanthracene, dibenzoanthracene, chrysene, benzo (b) fluoranthene and benzo (k) fluoranthene. 
These compounds are lipophilic and are transported by the lipoproteins of cell membranes, and are then accumulated in the fatty tissues of living organisms, thus entering the trophic chain, and causing serious disorders such as cancer, malformations and genetic mutations [58]. Furthermore, toxic effects related to PAHs have been found to cause cancer of the bladder, breast, esophagus, larynx, lung, liver, skin, pancreas and prostate [60].

- The toxic compounds found in the oil, but which are without carcinogenic effects used by the SimaPro software [61], are aromatic compounds such as toluene, ethylbenzene, xylene; aromatic compounds such as naphthalene, isopropyl benzene and biphenyl; aliphatic compounds such as hexane; and aliphatic compounds such as kerosene and fuel oil.

- Freshwater ecotoxicity: depending on the characteristics of the crude oil, it will form a complex with the surrounding soil, sediments, vegetation and water. When crude oil is mixed with water, it interacts with sediments forming Crude Oil Aggregate Particles (OPA). According to [62] (pp. 145-156), based on models of crude-sediment interactions, up to $65 \%$ of the volume of spilled crude is linked as OPA and the rest is partitioned directly in the water; this fraction is highly bioavailable, so its toxicity increases, affecting to aquatic ecosystems. It should be considered that for the case study, the water from estuaries is commonly used by the surrounding human population for the fulfillment of their vital functions; therefore, this contamination could affect their health.

- Eutrophication of freshwater: when crude oil is in contact with water, forms an oily layer on the surface that hinders gas exchange, increasing the amount of oxygen required by the biota in the water, favoring eutrophication [63].

- Depletion of water resources: it would represent the equivalent volume of water that cannot be used because is contaminated.

\subsubsection{Air Pollution}

Mainly, due to the generation of permanent gaseous emissions over time for the presence of crude oil and other pollutants in the environmental liability [58], semi-volatile VOCs are important precursors of organic secondary aerosols [64,65]. If the size of the aerosols is smaller than $100 \mathrm{~nm}$, they are considered ultra-fine particles and may travel very far distances from the oil spill site, with long residence times in the atmosphere thus increasing the radius of contamination. However, the final disposal and environmental impact of hydrocarbons in the atmosphere will be specific to the type of hydrocarbon and its physical state (dissolved or evaporated) is dependent on its initial partitioning by solubility or volatility [58].

Air pollution from oil spills would contribute to the following environmental categories:

- Climate change: $\mathrm{CO}_{2}$ contribution may be related to the area of contaminated soil without vegetation that stops sequestering carbon from the environment. Other studies have also shown that the presence of residual hydrocarbons, originated by oil extraction in soils with high levels of organic matter in anaerobic environments, promotes their decomposition and the formation of methane. In the context of climate change, the warming potential of methane is 25 times higher than $\mathrm{CO}_{2}$ [66]. In global terms, the environmental remediation of this liability prevented the release of $13.5 \mathrm{~kg}$ $\mathrm{CO}_{2}$ eq. to the environment per the LCA functional unit.

- Formation of photochemical smog and acidification: this is due to the interaction of hydrocarbons from the oil spill with nitrogen-oxides in the presence of light that would later return to the surface as acids [58]. 


\subsubsection{Soil Contamination}

Soil is affected by oil spills, and is where degradation routes such as bioaccumulation, volatilization, filtration, adsorption, and other chemical and physical-chemical processes take place [58]. This contamination is related to the following categories:

- Soil use: oil contamination affects in soil could cause damage to infiltration, stability and use of habitats. In turn, these generate midpoint impacts in the filtration and purification of water, regulation of the water flow, resistance and stability of the soil, functional diversity, diversity of species, and aesthetic and cultural values [56].

- Particulate matter: a possible cause of the higher concentration of particulate matter in this scenario would be the formation of stable pavements or structures on the soil surface or sediments contaminated with hydrocarbons that are not very soluble in water. Since they are combustible compounds, a considerable amount of black smoke with particulate matter is generated in the natural ignition process of the hydrocarbons, which despite containing minimal amounts of residual hydrocarbons, presents a potential risk to human health [58].

- Ionizing radiation for human health and ionizing radiation for ecosystems: the environmental impact would be related to the presence of radioactive waste in the environmental liability, because in the presumed date that the spill at well Sacha 124 occurred, environmental considerations for crude oil production did not meet adequate technical standards. According to [52], crude oil, sludge, formation waters and gas, among others, are a considerable source of TENORM, due to the high content of radionuclides in the rocks that have existed since the formation of the earth, which also accumulates over time [52,67-69]. A predominant factor is its characteristic of being bioaccumulative. It is necessary to emphasize that this category is "provisional", which means that the method used is the most appropriate compared to others, but that it requires even more development, so its results require validation before issuing a recommendation [70].

4.2.4. Air, Soil and Water Pollution Caused by Emissions, and Discharges Generated in the Production of Crude Oil

In the no-action scenario, 80,136 kg of oil crude were present in the oil spill. Therefore, the environmental loads associated to production of crude were considered by analyzing previous studies of the life cycle analysis of the production and refining process of petroleum [54,71,72]. Here, $\mathrm{CO}_{2}$ and $\mathrm{CH}_{4}$ are identified as predominant emissions that contribute mainly to climate change and the photochemical ozone formation. In addition, an important contribution is observed in the category of human toxicity, with carcinogenic and non-carcinogenic effects, freshwater ecotoxicity, acidification, eutrophication of freshwater and resource depletion. On the other hand, the refining process of petroleum shows that approximately $20 \%$ of the total contribution associated with ozone depletion and the significant generation of particulate matter is related to crude oil production [54].

\subsection{Weighted Results Analysis}

A greater impact was observed in the no-action scenario. This would be related mainly to the environmental loads corresponding to acidification. Regarding the impact on human health, where the impact of environmental strategy scenario is lower by $39 \%$, this decrease would be mainly related to the category of ionizing radiation, according to the difference of 1.04 points between both scenarios. In the group corresponding to the impact on the availability of resources, an environmental contribution lower by $36 \%$ was determined in the remediation scenario, mainly related to the category of photochemical ozone formation with a difference of 0.18 points between the two scenarios evaluated.

Our results are consistent with previous studies where the impact of executing remediation activities was compared with no-action. In the study carried out by [73], the application of bioremediation through biopiles to soils contaminated with diesel was evaluated. It was observed that the presence of contamination in soils constituted the most 
important contribution to global environmental impacts in an order of 1 to 10 if is compared with soils that were remediated. Likewise, in similar studies developed by [38], it was determined that remediation technologies have a positive impact on the environment and health of people. In other words, the environmental cost of carrying out environmental remediation is lower than the environmental cost of leaving the contamination in the soil.

\subsection{Improvement Strategies in Environmental Remediation Processes}

Based on the environmental categories that presented the highest values in the environmental remediation scenario, the following improvement opportunities were identified.

Regarding the use of vehicles and heavy machinery, it would be useful to review the routes used by vehicles and heavy machinery to optimize distances and reduce mileage, preventative and corrective maintenance programs that ensure optimal working conditions cannot be neglected. Sharing vehicles for activities in nearby places must be considered.

Concerning the use of PPE, it is advisable to review the technical specifications involved in looking for alternatives for materials that both meet the safety requirements and have a longer durability than the current ones, to reduce the generation of hazardous waste when incinerated. If it is not possible to find materials with longer durability, would be necessary to choose materials with less hazardous effects once incinerated. It is advisable to carry out the associated risk analysis in the workers directly involved in the remediation to evaluate the best PPE they should use.

Another aspect of improvement is the evaluation of alternative surfactants used in soil washing and the selection of the options with higher biodegradability.

\section{Conclusions}

The remediation process of spill-type pollution sources carried out in this study was environmentally evaluated using LCA methodology, followed the procedure stated at ISO 14040 and ISO 4044 standards and was thencompared with the scenario of no-action. The environmental characterization indicates a greater positive environmental impact in the environmental remediation scenario in 12 out of the 16 environmental categories evaluated, with a global score of 5.45 points for no-action and 3.3 points for the environmental strategy carried out. This fact reflects that the execution of remediation on environmental liabilities reduces the global environmental impact, indeed approximately $39.4 \%$ for our case of study. Regarding the groups of categories of the final affectation, a reduction of $43 \%$ in the environmental impact was reach to the ecosystem impacts, followed by $39 \%$ for the affectation to human health impacts and $36 \%$ for resources depletion. Therefore, evaluated remediation activities on this study contributed positively to mitigate the environmental effects generated by the presence of sources of pollution associated with wastes from hydrocarbon activity in the Ecuadorian Amazon. However, improvements of the process have not been ruled out.

Supplementary Materials: The following are available online at https:/ / www.mdpi.com/article/ 10.3390/pollutants1040019/s1. Table S1: Assumptions and limitations considered in the life cycle assessment of remediation activities of the environmental liability SA_124_02D, Table S2: Environmental impacts related to the manufacture of supplies and personal protection equipment in remediation activities.

Author Contributions: Conceptualization, K.G.-V., L.R.-G.; methodology, K.G.-V., L.R.-G. and J.L.C.; investigation, K.G.-V.; data curation, L.R.-G. and J.L.C.; writing-original draft preparation, K.G.-V.; writing-review and editing, L.R.-G., P.V.-J. and D.H.-L.; project administration, K.G.-V.; funding acquisition, K.G.-V. All authors have read and agreed to the published version of the manuscript.

Funding: This research was funded by EP PETROECUADOR thorough the budget destined for decontamination activities of its Project Amazonia Viva.

Institutional Review Board Statement: Not applicable.

Informed Consent Statement: Not applicable. 


\section{Data Availability Statement: Not applicable.}

Acknowledgments: The authors thank EP PETROECUADOR for funding this research project, ISM for making software and databases available for calculating the LCA and to the ESPE and UTE Universities for all the support provided during the development of this project.

Conflicts of Interest: The authors declare no conflict of interest. The funder had no role in the design of the study; in the collection, analyses, or interpretation of data; in the writing of the manuscript, or in the decision to publish the results.

\section{References}

1. Banco Central del Ecuador. Evolución de la Balanza Comercial. Available online: https://www.bce.fin.ec/index.php/component/ k2/item/299-evoluci\%C3\%B3n-de-la-balanza-comercial (accessed on 8 September 2020).

2. Observatorio Económico y Social de Tungurahua. Universidad Técnica de Ambato. Available online: https://blogs.cedia.org.ec/ obest/wp-content/uploads/sites/7/2020/09/EL-SECTOR-PETROLERO.pdf (accessed on 8 September 2021).

3. Baynard, C.W.; Ellis, J.M.; Davis, H. Roads, petroleum and accessibility: The case of eastern Ecuador. GeoJournal 2013, 78, 675-695. [CrossRef]

4. PETROAMAZONAS EP, “Nuestra Producción”. Available online: https://www.petroamazonas.gob.ec/?p=148 (accessed on 14 December 2020).

5. Programa de Reparación Ambiental y Social del Ministerio del Ambiente y Transición Ecológica del Ecuador. Available online: http:/ / pras.ambiente.gob.ec/documents /228536/737569/Plan+de+Reparaci\%C3\%B3n+de+Pacayacu+-+Final-1+_1_. pdf/2edd1e88-566c-413b-a422-b7ac3bfe46d3 (accessed on 11 January 2021).

6. Recalde, C.A. Diseño Metodológico para el Análisis Comparativo de Técnicas de Remediación ex situ: Compostaje en Biopilas, Bioaumentación y Bioestimulación, aplicadas para la Degradación de Hidrocarburos en los Procesos de Remediación de Suelos que ejecuta la Gerencia Amazonía Viva. Master's Thesis, Universidad Central del Ecuador, Quito, Ecuador, February 2017.

7. Chukwuka, K.S.; Alimba, C.G.; Ataguba, G.A.; Jimoh, W.A. The Impacts of Petroleum Production on Terrestrial Fauna and Flora in the Oil-Producing Region of Nigeria. In The Political Ecology of Oil and Gas Activities in the Nigerian Aquatic Ecosystem, 1st ed.; Nimdele, P., Ed.; Elsevier Inc: London, UK, 2018; Volume 1, pp. 125-142.

8. Olawuyi, D.S. Environmental Impacts and Risks of Exractive Operations. In Extractives Industry Law in Africa, 1st ed.; Nimdele, P., Ed.; Springer International Publishing: Switzerland, Sweden, 2018; Volume 1, pp. 269-322.

9. Ossai, I.C.; Ahmed, A.; Hassan, A.; Hamid, F.S. Remediation of soil and water contaminated with petroleum hydrocarbon: A review. Environ. Technol. Innov. 2020, 17, 100526. [CrossRef]

10. Lin, M.C.; Yu, H.S.; Tsai, S.S.; Cheng, B.H.; Hsu, T.Y.; Wu, T.N.; Yang, C.Y. Adverse pregnancy outcome in a petrochemical polluted area in Taiwan. J. Toxicol. Environ. Heal.-Part A 2001,63, 565-574. [CrossRef]

11. Yang, C.Y.; Chang, C.C.; Chuang, H.Y.; Ho, C.K.; Wu, T.N.; Chang, P.Y. Increased risk of preterm delivery among people living near the three oil refineries in Taiwan. Environ. Int. 2004, 30, 337-342. [CrossRef]

12. Paz-y-Miño, C.; López-Cortés, A.; Muñoz, M.J.; Cabrera, A. Impacto genético en comunidades Amazónicas del Ecuador localizadas en zonas petroleras. Rev. Ecuat. Med. Cienc. Biol. 2010, 31, 7-19. [CrossRef]

13. Pathakoti, K.; Manubolu, M.; Hwang, H.M. Chapter 48: Nanotechnology applications for environmental industry. In Handbook of Nanomaterials for Industrial Applications, 1st ed.; Hussain, C.M., Ed.; Elsevier: Amsterdam, The Netherlands, 2018; Volume 1, pp. 894-907. [CrossRef]

14. Lemming, G.; Hauschild, M.; Bjerg, P.L. Life cycle assessment of soil and groundwater remediation technologies: Literature review. Int. J. Life Cycle Assess. 2010, 15, 115-127. [CrossRef]

15. Harclerode, M.A.; Lal, P.; Miller, M.E. Quantifying Global Impacts to Society from the Consumption of Natural Resources during Environmental Remediation Activities. J. Ind. Ecol. 2016, 20, 410-422. [CrossRef]

16. Busset, G.; Sangely, M.; Montrejaud-Vignoles, M.; Thannberger, L.; Sablayrolles, C. Life cycle assessment of polychlorinated biphenyl contaminated soil remediation processes. Int. J. Life Cycle Assess. 2012, 17, 325-336. [CrossRef]

17. Lemming, G.; Nielsen, S.G.; Weber, K.; Heron, G.; Baker, R.; Falkenberg, J.A.; Terkelsen, M.; Jensen, C.B.; Bjerg, P.L. Optimizing the environmental performance of in situ thermal remediation technologies using life cycle assessment. Groundw. Monit. Remediat. 2013, 33, 38-51. [CrossRef]

18. Yasutaka, T.; Zhang, H.; Murayama, K.; Hama, Y.; Tsukada, Y.; Furukawa, Y. Development of a green remediation tool in Japan. Sci. Total Environ. 2016, 563-564, 813-821. [CrossRef]

19. Hou, D.; Qi, S.; Zhao, B.; Rigby, M.; O'Connor, D. Incorporating life cycle assessment with health risk assessment to select the "greenest" cleanup level for Pb contaminated soil. J. Clean. Prod. 2017, 162, 1157-1168. [CrossRef]

20. Hou, D.; Al-Tabbaa, A. Sustainability: A new imperative in contaminated land remediation. Environ. Sci. Policy 2014, 39, 25-34. [CrossRef]

21. Sparrevik, M.; Saloranta, T.; Cornelissen, G.; Eek, E.; Fet, A.M.; Breedveld, G.D.; Linkov, I. Use of life cycle assessments to evaluate the environmental footprint of contaminated sediment remediation. Environ. Sci. Technol. 2011, 45, 4235-4241. [CrossRef] [PubMed] 
22. Gobierno Autonomo Descentralizado de la Provincia de Orellana. Available online: https://www.gporellana.gob.ec/wpcontent/uploads/2015/11/PDYOT-2015-2019_ORELLANA_ACTUALIZADO.pdf (accessed on 9 November 2021).

23. Instituto Geográfico Militar. Especificaciones Técnicas para la Producción de Cartografía Escala 1:5000. Available online: http:/ / www.geoportaligm.gob.ec/portal/?wpfb_dl=851 (accessed on 9 November 2021).

24. United States Environmental Protection Agency. SW-846 Test Method 8440: Total Recoverable Petroleum Hydrocarbons by Infrared Spectrophotometry. Available online: https:/ / www.epa.gov/hw-sw846/sw-846-test-method-8440-total-recoverablepetroleum-hydrocarbons-infrared-spectrophotometry (accessed on 9 November 2021).

25. Portal Único de Trámites Ciudadanos. Acuerdo Ministerial 097-A, Anexos de Normativa, Reforma libro VI del Texto Unificado de Legislacion Secundaria del Ministerio del Ambiente. Available online: https://www.gob.ec/regulaciones/acuerdo-ministerial097-anexos-normativa-reforma-libro-vi-texto-unificado-legislacion-secundaria-ministerio-ambiente (accessed on 9 November 2021).

26. Ministerio de Ambiente, Agua y Transición Ecológica. Reglamento Ambiental para Operaciones Hidrocarburíferas Decreto Ejecutivo Nro. 1215. Available online: https://www.ambiente.gob.ec/wp-content/uploads/downloads/2012/09/RAOHEDECRETO-EJECUTIVO-1215.pdf (accessed on 9 November 2021).

27. Yan, M.; Wang, D.; Qu, J.; Ni, J.; Chow, C. Enhanced coagulation for high alkalinity and micro-polluted water: The third way through coagulant optimization. Water Research. 2008, 42, 2278-2286. [CrossRef]

28. International Organization for Standarization. ISO 14040:2006. Environmental Management—Life Cycle Assessment-Principles and Framework. Available online: https:/ / www.iso.org/obp/ui\#tiso:std:iso:14040:ed-2:v1:es (accessed on 9 November 2021).

29. International Organization for Standarization. ISO 14044:2006. Environmental Management-Life Cycle AssessmentRequirements and Guidelines. Available online: https://www.iso.org/obp/ui/\#iso:std:iso:14044:ed-1:v1:es (accessed on 9 November 2021).

30. Simapro. Ecoinvent LCI Database. Available online: https:/ / simapro.com/databases/ecoinvent/ (accessed on 10 January 2020).

31. Simapro. Licenses. Available online: https://simapro.com/ (accessed on 10 January 2020).

32. Pre-sustainability. Update of the ILCDE Midpoint Method Version 1.04 in Simapro. Available online: https:/ / pre-sustainability. com/files/2014/09/Update-of-the-ILCD-2011-Midpoint-method-1.pdf (accessed on 3 January 2021).

33. Sleeswijk, A.W.; Van Oers, L.F.; Guinée, J.B.; Struijs, J.; Huijbregts, M.A.J. Normalisation in product life cycle assessment: An LCA of the global and European economic systems in the year 2000. Sci. Total Environ. 2008, 390, 227-240. [CrossRef]

34. Montzka, S.A.; Dlugokencky, E.J.; Butler, J.H. Non- $\mathrm{CO}_{2}$ greenhouse gases and climate change. Nature 2011, 476, 43-50. [CrossRef]

35. Singh, H. Reactive nitrogen in the troposphere. Environ. Sci. Techonology 1987, 21, 320-327. [CrossRef]

36. Wuebbles, D.J. Nitrous oxide: No laughing matter. Science 2009, 326, 56-57. [CrossRef]

37. Ravishankara, A.R.; Daniel, J.S.; Portmann, R.W. Nitrous oxide $\left(\mathrm{N}_{2} \mathrm{O}\right)$ : The dominant ozone-depleting substance emitted in the 21st century. Science 2009, 326, 123-125. [CrossRef] [PubMed]

38. Suer, P.; Andersson-Skold, Y.; Andersson, J. Local Gain, Global Loss: The Environmental Cost of Action. In Advances in Applied Bioremediation, 1st ed.; Singh, A., Kuhad, R.C., Ward, O.P., Eds.; Springer: Berlin/Heidelberg, Germany, 2009; Volume 17, pp. 21-34. [CrossRef]

39. Ramana, M.V.; Ramathan, V.; Feng, Y.; Yoon, S.C.; Kim, S.W.; Carmichael, G.R. Warming influenced by the ratio of black carbon to sulphate and the black-carbon source. Nat. Geosci. 2010, 3, 542-545. [CrossRef]

40. Ramanathan, V.; Carmichael, G. Global and regional climate changes due to black carbon. Nat. Geosci. 2008, 1, 221-227. [CrossRef]

41. Ban-Weiss, G.A.; McLaughlin, J.P.; Harley, R.A.; Lunden, M.M.; Kirchstetter, T.W.; Kean, A.J.; Strawa, A.W.; Stevenson, E.D.; Kendall, G.R. Long-term changes in emissions of nitrogen oxides and particulate matter from on-road gasoline and diesel vehicles. Atmos. Environ. 2008, 42, 220-232. [CrossRef]

42. Johnson, E. Cars and ground-level ozone: How do fuels compare? Eur. Transp. Res. Rev. 2017, 9, 1-13. [CrossRef]

43. Huang, Y.; Chen, H.; Lu, Y.; Liu, B.; Shi, H.; Xiao, T. A novel process to recover sulfur in aqueous phase under ambient condition. Appl. Petrochem. Res. 2015, 5, 207-213. [CrossRef]

44. Prado, G.H.C.; Rao, Y.; De Klerk, A. Nitrogen removal from oil: A review. Energy Fuels 2017, 31, 14-36. [CrossRef]

45. Beér, J.M. Minimizing NOx emissions from stationary combustion; reaction engineering methodology. Chem. Eng. Sci. 1994, 49, 4067-4083. [CrossRef]

46. Manisalidis, I.; Stavropoulou, E.; Stavropoulos, A.; Bezirtzoglou, E. Environmental and Health Impacts of Air Pollution: A Review. Front. Public Health 2020, 8, 14. [CrossRef] [PubMed]

47. Turconi, R.; Butera, S.; Boldrin, A.; Grosso, M.; Rigamonti, L.; Astrup, T. Life cycle assessment of waste incineration in Denmark and Italy using two LCA models. Waste Manag. Res. 2011, 29, 78-90. [CrossRef]

48. Hong, J.; Han, X.; Chen, Y.; Wang, M.; Ye, L.; Qi, C.; Li, X. Life cycle environmental assessment of industrial hazardous waste incineration and landfilling in China. Int. J. Life Cycle Assess. 2017, 22, 1054-1064. [CrossRef]

49. Allsopp, P.; Costner, M.; Johnston, P. Incineration and Human Health. Environ. Sci. Pollut. Resour. 2001, 8, 141-145. [CrossRef]

50. Cheng, M.; Zeng, G.; Huang, D.; Yang, C.; Lai, C.; Zhang, C.; Liu, Y. Tween 80 surfactant-enhanced bioremediation: Toward a solution to the soil contamination by hydrophobic organic compounds. Crit. Rev. Biotechnol. 2018, 38, 17-30. [CrossRef]

51. Karthick, A.; Roy, B.; Chattopadhyay, P. A review on the application of chemical surfactant and surfactant foam for remediation of petroleum oil contaminated soil. J. Environ. Manage. 2019, 243, 87-205. [CrossRef] 
52. Ali, M.M.M.; Zhao, H.; Li, Z.; Maglas, N.N.M. Concentrations of TENORMs in the petroleum industry and their environmental and health effects. RSC Adv. 2019, 9, 39201-39229. [CrossRef]

53. Suárez, O.; Gonzalez, Y. Tenorm en el Ecuador: Inventario preliminar y el papel de la autoridad reguladora. In Proceedings of the VIII Congr. Reg. Segur. Radiológica y Nucl. I Congr. Latinoam. del IRPA y V Congr. Nac. Protección Radiológica DSSA, Medellín, Colombia, 11 October 2010. Available online: https://www.researchgate.net/profile/Omar-Suarez-3/ publication/261651276_TENORM_EN_EL_ECUADOR_INVENTARIO_PRELIMINAR_Y_EL_PAPEL_DE_LA_AUTORIDAD_ REGULADORA/links/02e7e534ed2b86c03c000000/TENORM-EN-EL-ECUADOR-INVENTARIO-PRELIMINAR-Y-EL-

PAPEL-DE-LA-AUTORIDAD-REGULADORA.pdf (accessed on 3 January 2021).

54. Liu, Y.; Lu, S.; Yan, X.; Gao, S.; Cui, X.; Cui, Z. Life cycle assessment of petroleum refining process: A case study in China. J. Clean. Prod. 2020, 256, 120422. [CrossRef]

55. I Canals, L.M.; Bauer, C.; Depestele, J.; Dubreuil, A.; Knuchel, R.; Gaillard, G.; Michelsen, O.; Muller-Wenk, R.; Rydgren, B. Key elements in a framework for land use impact assessment within LCA. Int. J. Life Cycle Assess. 2007, 12, 2-4. [CrossRef]

56. Koellner, T.; Baan, L.; Beck, T.; Brandao, M.; Civit, B.; Margni, M.; Milà, I.; Canals, L.; Saad, R.; De Souza, D.M.; et al. UNEP-SETAC guideline on global land use impact assessment on biodiversity and ecosystem services in LCA. Int. J. Life Cycle Assess. 2013, 18, 1188-1202. [CrossRef]

57. Rivera, F. Propuesta de Zonificación Ecológica del cantón La Joya de los Sachas, provincia de Orellana. Thesis to the grade of Geographic Engineer, Pontificia Universidad Católica del Ecuador, Quito, Ecuador, February 2013.

58. Kuppusamy, S.; Maddela, N.R.; Megharaj, M.; Venkateswarlu, K. Total Petroleum Hydrocarbons. Environmental Fate, Toxicity, and Remediation, 1st ed.; Springer Nature Switzerland AG: Cham, Switzerland, 2005; pp. 57-74.

59. Ramadass, K.; Megharaj, M.; Venkateswarlu, K.; Naidu, R. Ecotoxicity of measured concentrations of soil-applied diesel: Effects on earthworm survival, dehydrogenase, urease and nitrification activities. Appl. Soil Ecol. 2017, 119, 1-7. [CrossRef]

60. Xu, X.; Hu, H.; Kearney, G.D.; Kan, H.; Sheps, D.S. Studying the effects of polycyclic aromatic hydrocarbons on peripheral arterial disease in the United States. Sci. Total Environ. 2013, 461-462, 341-347. [CrossRef]

61. SimaPro Database Manual Methods Library. Available online: https://simapro.com/wp-content/uploads/2020/10/ DatabaseManualMethods.pdf (accessed on 10 November 2021).

62. Bandara, U.C.; Yapa, P.D.; Xie, H. Fate and transport of oil in sediment laden marine waters. J. Hydro-Environ. Res. 2011, 5, 145-156. [CrossRef]

63. Werner, M.D.; Adams, V.D.; Lamarra, V.A. An Experimental Investigation of the Effects of Crude Oil on Two Freshwater Lake Ecosystems. Reports 1983, 1-213.

64. Robinson, A.L.; Donahue, N.M.; Shrivastava, M.K.; Weitkamp, E.A.; Sage, A.M.; Grieshop, A.P.; Lane, T.E.; Pierce, J.R.; Pandis, S.N. Rethinking organic aerosols: Semivolatile emissions and photochemical aging. Science 2007, 315, 1259-1262. [CrossRef]

65. Ryerson, T.B.; Aikin, K.C.; Angevine, W.M.; Atlas, E.L.; Blake, D.R.; Brock, C.A.; Fehsenfeld, F.C.; Gao, R.S.; de Gouw, J.A.; Fahey, D.W.; et al. Atmospheric emissions from the deepwater Horizon spill constrain air-water partitioning, hydrocarbon fate, and leak rate. Geophys. Res. Lett. 2011, 38, 6-11. [CrossRef]

66. Life Cycle Associates, LCC. Assessment of Direct and Indirect GHG Emissions Associated with Petroleum Fuels. Available online: https:/ / ethanolrfa.org/file/851/NFA_PImpacts_v35.pdf (accessed on 10 November 2021).

67. United States Environmental Protection Agency. TENORM: Oil and Gas Production Wastes. Available online: https://www.epa. gov/radiation/tenorm-oil-and-gas-production-wastes (accessed on 10 November 2021).

68. Garnier-Laplace, J.; Beaugelin-Seiller, K.; Gilbin, R.; Della-Vedova, C.; Jolliet, O.; Payet, J. A Screening Level Ecological Risk Assessment and ranking method for liquid radioactive and chemical mixtures released by nuclear facilities under normal operating conditions. Radioprotection 2009, 44, 903-908. [CrossRef]

69. Michalik, B.; Wysocka, M.; Liland, A. Survey of the impact of enhanced natural radioactivity on human and natural environments: The example based on PORANO project. Radioprotection 2011, 46, 681-685. [CrossRef]

70. European Commission, Characterisation factors of the ILCD Recommended Life Cycle Impact Assessment methods: Database and Supporting Information. Available online: https:/ / eplca.jrc.ec.europa.eu/uploads/LCIA-characterization-factors-of-theILCD.pdf (accessed on 10 November 2021).

71. Yang, R.; Ozer, H.; Al-Qadi, I.L. Regional upstream life-cycle impacts of petroleum products in the United States. J. Clean. Prod. 2016, 139, 1138-1149. [CrossRef]

72. Morales, M.; Gonzalez-García, S.; Aroca, G.; Moreira, M.T. Life cycle assessment of gasoline production and use in Chile. Sci. Total Environ. 2015, 505, 833-843. [CrossRef]

73. Toffoletto, L.; Deschênes, L.; Samson, R. LCA of ex-situ bioremediation of diesel-contaminated soil. Int. J. Life Cycle Assess. 2005, 10, 406-416. [CrossRef] 